\title{
The Effect of Learning Styles, Motivation and Science Learning Facilities on the Students' Outcomes in Learning Science at 5 Grade of Elementry School
}

\author{
Nuri Rmadhan, Sahyar, Sondang Manurung \\ Departement of Elemetry School \\ Medan State University \\ Medan, Indonesia \\ email: Nuhriramadhan@gmail.com
}

\begin{abstract}
This study is aimed to analyze the influence of learning style, motivation, and science learning facilities on the achievement of students in learning science. This research was conducted at grade five Elementry School with a population of 269 students. The samples of this study were 160 students using proportional random sampling method. The instrument used in this study is a questionnaire that has been tested the validity and reliability. Whereas, data analysis technique used is multiple linear regression. The result of hypothesis test simultaneously, learning style, motivation and facility of science lesson have positive and significant impact to the achievement of students in learning science. Thus, it can be concluded that the learning style, motivation and science learning facilities has a positive and significant effect on the achievement of students.

Keywords—learning style, motivation, science learning facilities
\end{abstract}

\section{INTRODUCTION}

Science is one of the main subjects in the education curriculum, including at the elementary school level. Basically, science is a method of finding out about nature systematically to master a collection of knowledge in the form of facts, concepts, principles, discovery processes and scientific attitudes. It has implications for science learning activities. Science and science learning are not just scientific knowledge, but contain science, process skills and dimensions that focus on the characteristics of scientific attitudes and character [1]. According to the program for international student assessment (PISA) held every 3 years since 2000, includes 15 years old students from 76 countries, both developed and developing countries. PISA assessment criteria include cognitive abilities, and students' skills in reading, mathematics, and science.

According to the PISA record in 2009, students in Indonesia generally only mastered subjects up to level 3 , while many students from other countries mastered the subjects up to level 4, 5, and even 6. PISA survey found that in 2013 Indonesia rank was in 64 while the results of the PISA survey in 2015, Indonesia rank was at the bottom 8 of 76 countries participating in the PISA [2]. The quality of mastering science in Indonesia is very poor and categorized into a low category.
Certainly, this is the concern of all education practitioners, especially in the study of Sciences in Elemetry Schools [3]

Various problems in the implementation of science education that are in accordance with the nature are very complex. Therefore, the thoughts are still being contributed to solving the problem. Science education is faced with problems between science learning tools that are able to integrate various disciplines through specific themes, between concepts in one subject with the concept of other subjects, so that teachers and students have the provision of competencies in various disciplines. But the problem of basic science learning is how the students learn at school and at home, external and internal motivation of the students and adequate science learning facilities that will affect student's achievement.

In the learning process, the elements of the learning process play an important role. The core of educational activities is teaching and learning activities. The success of students in participating in school education programs is seen based on their learning outcomes. Learning outcomes are the result of an interaction between learning and teaching. In terms of the teacher, the teaching action ends with the process of evaluating learning outcomes. In terms of students, learning outcomes is the end of the peak of learning [4]. Student learning outcomes are essentially behavioral changes as learning outcomes in a broader sense covering the cognitive, affective and psychomotor fields [5].

Generally, there are two factors that influence student learning outcomes, namely internal factors and external factors. Internal factors are factors that come from within students. These factors include physiological factors (health and body condition), psychological (interests, talents, intelligence, emotions, fatigue, and ways of learning). Meanwhile, external factors are factors that come from outside of the student. These factors include family environment, school environment, community environment, and natural environment. All of these factors must contribute synergistically to each other because it affects learning achievement and in order to assist students in achieving the best learning achievement [6].

One factor that can influence student learning outcomes is internal factors, namely learning. How to learn is a way of 
how students carry out learning activities such as how they prepare to learn, understand the lessons, do independent learning activities, how to face the exam. The quality of learning will determine the quality of learning outcomes obtained. A good way of learning will lead to successful learning. Many students and or students fail or do not get good results in learning because they do not know the ways of effective learning [7].

Success in learning is also determined by motivation if in itself there is a desire to learn. Learning outcomes will be optimal if there is the right motivation [8]. In learning activities, motivation can be said as the overall driving force in students that lead learning activities, which ensures the continuity of learning activities and which provides direction learning activities, so that the desired goals by the subject of learning can be achieved. Another factor that can affect student learning outcomes is learning facilities. In Indonesian dictionary, facilities are all things that can facilitate things (smooth tasks and so on) or ease [9].

Learning facilities are all that is needed in the teaching and learning process both moving and not moving so that the educational objectives can run smoothly, regularly, effectively and efficiently [10]. Learning facilities as a supporting element of learning, there are three things that need our attention, namely media or tools, learning equipment, and classroom [11]. These three components interrelate and influence. Overall, these three components contribute, both individually and jointly to activities and learning success.

Kabanjahe District is a sub-district in North Sumatra, Karo Regency. According to information received from the Karo district education service, there are 36 elementary schools in Kabanjahe District, both state and private. Based on the information obtained by the researchers from several fifth grade elementary school teachers in Kabanjahe Subdistrict, from fifth grade students only about $35 \%$ of students had good learning methods and high learning motivation, while $65 \%$ of other students had good learning methods but have low motivation in learning. On the contrary, there are students who have high motivation but learning methods are not good and this will affect student learning outcomes.

In addition, learning and motivation that are factors of learning outcomes, facilitation is also closely related to learning outcomes. Without facilities in school, students cannot improve their learning outcomes. Learning facilities can be seen from the place where learning activities were carried out [12]. From the information obtained from several teachers teaching in 5 Grade in Kabanjahe sub-district, most of the science learning facilities are not adequate even in some schools there is no practical science equipment for them. Even though, their science learning facilities are already but most teachers have not used it maximally, even rarely used by teachers. Not only that in some schools, the room for the lab of science is also inadequate and even eliminated.

Several studies almost have the same variables have been carried out. The results showed that learning facilities had a positive and significant effect on student learning motivation on productive subjects of state vocational office administration, Bandung [13]. Furthermore, there is a study entitled "The Effect of Learning Motivation and Utilization of Learning Facilities on Student Learning Achievement in Economics Class XI Social Sciences in Surabaya Muhamadiyah 2 High School" [14]. The results of the study simultaneously have an influence between learning motivation and utilization of learning facilities on learning achievement, it can be seen from the results of the analysis of $F_{\text {count }} 3,974306>$ 3,12 .

Regarding to the conditions above it can be concluded that the learning outcomes achieved by students in school are not satisfactory. From the information obtained from some elementary school at fifth grade teachers in Kabanjahe, it appears that the students' science learning outcomes at semester examination scores have not reached the classical completeness of $\geq 85 \%$. And students also have not reached their completeness individually or achieved the Minimum Completeness Criteria which is $\geq 70$.

\section{RESEARCH METHODLOGY}

This research was carried out in three elementary schools in Kabanjahe Subdistrict, Karo Regency, namely Elementary School 040444, Elementary School 040452 and Methodis Elemetry School, Kabanjahe. The author will conduct research by conducting questionnaire distribution techniques to students with predetermined locations. Data sources used in this study are primary and secondary data sources. Primary data is data obtained directly by field surveys that use all original data collection methods. The method that can be used to collect primary data is through the distribution of questionnaires, documentation and direct observation. Secondary data is data that has been collected by collection agencies and published to the data user community. Secondary data in this study were taken from previous researchers and electronic media.

The population of this study was the fifth grade students of 040444 Elementary School and Methodist Elementary School with total poppulation was 269 students. Sampling in this study used proportional random sampling method. To calculate the size of the sample can be done using Slovin technique with the formula [15]:

$$
n=\frac{N}{1+N_{l}^{2}}
$$

Based on the formula above, the sample size is 160 samples. Whereas to determine the number of samples in each section by averaging the number of samples into each group, the formula is:

$$
n=\frac{X}{N} \times N_{1}
$$


From the formula obtained above, the number of samples from each part, namely 040444 Elementary School as many as 38 students, 040452 Elementary School as many as 25 students and Methodist Elementary School as many as 97 students. This study consists of independent variables and dependent variables.

Data collection techniques used to obtain the data needed is documentation and questionnaires. In analyzing the results of the data that has been obtained from the field data processing will be carried out, so that the results can be used as a reference in completing this research. The data analysis techniques that would be carried out are:

1. Data quality test (validity and reliability),

2. Classic assumption test (normality test, multicollinearity test, heteroscedasticity test),

3. Multiple regression analysis,

4. Hypothesis testing $\left(\mathrm{F}_{\text {test }}\right.$ and $\left.\mathrm{T}_{\text {test }}\right)$,

5. Determinant coefficient.

\section{RESEARCH FINDINGS}

After doing the research with 160 respondents, namely the fifth grade students in the Elementary School in Kabanjahe sub-district, the results of questionnaire distribution can be processed using data analysis techniques.

\section{A. Test Validity and Reliability}

For testing the validity of the Questionnaire is used Product Moment Correlation formula and to test the reliability of the Questionnaire is used Cronbach Alpha formula. This research questionnaire is valid if $r_{\text {count }}>r_{\text {table }}$ at level $\alpha=0.05$. $=0.05$ for 30 respondents of 0.361 . For this reason, the instrument was tested on 30 respondents, using the product moment correlation technique. To find out the validity of the questionnaire is done by comparing $r_{\text {table }}$ with $r_{\text {count }}$, the value of $r_{\text {table }}$ with a significant level.

From the calculation data by using SPSS 22.0 for Windows program, the results of the validity of the Learning Style $\left(\mathrm{X}_{1}\right)$ variable indicates that from 24 questions in questions 4 and 21 it is invalid because $r_{\text {count }}<r_{\text {table }}$ with the number $0.078<0.361$ and $0.215<0.361$. So, from 24 questions for learning style variables, 22 questions are worth using in this study. Then the results of the reliability calculation using the Cronbach's Alpha test are stated as follows:

TABLE 1. Reliability Statistics $\left(\mathrm{X}_{1}\right)$

\begin{tabular}{|c|c|}
\hline Cronbach's Alpha & N of Items \\
\hline 0,797 & 24 \\
\hline
\end{tabular}

Based on the table above, it can be stated that 24 items for the Learning Style $\left(\mathrm{X}_{1}\right)$ variable are reliable because alpha cronbach's $>r_{\text {table }}$, where $0.797>0.361$.
For the results of the validity of the Motivation variable $\left(\mathrm{X}_{2}\right)$ shows that from22 questionnaire questions about motivation shows that $r_{\text {count }}>r_{\text {table }}$ with the conclusion that all questionnaire questions are classified as valid and feasible to be used in this study. The results of reliability calculations using the Cronbach's Alpha test are stated as follows:

\section{TABLE 2. Reliability Statistics $\left(\mathrm{X}_{2}\right)$}

\begin{tabular}{|c|c|}
\hline Cronbach's Alpha & N of Items \\
\hline 0,877 & 22 \\
\hline
\end{tabular}

Based on the table above, it can be stated that the 22 items for the motivation variable $\left(\mathrm{X}_{2}\right)$ are reliable because alpha cronbach's $>r_{\text {table, }}$, where $0.877>0.361$. And for the results of the validity of the variable Science Learning Facilities $\left(\mathrm{X}_{3}\right)$ shows that from 31 questionnaire questions about science learning facilities shows that $r_{\text {count }}>$ rtable with the conclusion that all questionnaire questions are classified as valid and feasible to be used in this study. The results of reliability calculations using the Cronbach's Alpha test are stated as follows:

TABLE 3. Reliability Statistics $\left(\mathrm{X}_{3}\right)$

\begin{tabular}{|c|c|}
\hline Cronbach's Alpha & N of Items \\
\hline 0,785 & 8 \\
\hline
\end{tabular}

Berdasarkan pada tabel di atas, maka dapat dinyatakan bahwa 33 item untuk variabel fasilitas belajar IPA $\left(\mathrm{X}_{3}\right)$ tersebut adalah reliabel karena alpha cronbach's $>\mathrm{r}_{\text {tabel }}$, dimana $0,785>0,361$.

\section{B. Classic Assumption Test}

To obtain linear regression results, a classic assumption test would be used. Classical assumption test aims to test a model that is feasible or not feasible to be used in this study. In the classical assumption test using three tests namely normality test, multicollinearity test, heteroscedasticity test. Testing normality in this study is used by looking at the normal probability plot which compares the cumulative distribution of actual data with the cumulative distribution of normal distribution. To detect whether the regression model used is free from multicollinearity problems can be seen from the large VIF (Variance Inflation Factor) and tolerance, where the VIF value is not more than 10 and the tolerance value is not less than 0.1 . Multicollinearity test results in the following table: 
TABLE 4. Multikolinearitas Coefficients ${ }^{\mathrm{a}}$ Test

\begin{tabular}{|cc|r|r|}
\hline \multirow{2}{*}{} & \multirow{2}{*}{ Model } & \multicolumn{2}{|c|}{$\begin{array}{c}\text { Collinearity } \\
\text { Statistics }\end{array}$} \\
\cline { 2 - 4 } & Tolerance & VIF \\
\hline $1 \quad$ (Constant) & & \\
Learning Style &, 273 & 3,656 \\
Motivation &, 275 & 3,636 \\
Learning & & \\
Science &, 391 & 2,556 \\
facilities & & \\
\hline
\end{tabular}

Based on the table above, it can be seen that all independent variables namely Learning Style, Learning Motivation and Functionality have a Variance Inflation Factors (VIF) number below 10 with a tolerance number that shows a value of more than 0.1 . In the coefficient section contained in the output it can be seen that tolerance is worth $\left(\mathrm{X}_{1}\right)=0.273,\left(\mathrm{X}_{2}\right)=0.275$, and $\left(\mathrm{X}_{3}\right)=0.391$ While VIF is worth $\left(\mathrm{X}_{1}\right)=3.656,\left(\mathrm{X}_{2}\right)=3.636$, and $\left(\mathrm{X}_{3}\right)=2,556$. It shows that VIF and tolerance have values above 0.1 and not more than 10 , which means that they are free of multicollinearity problems.

\section{Hypothesis Test}

The analysis model used in this study is multiple regression. Multiple regression analysis was carried out to find out how much the influence of the independent variables (Learning Styles, Motivation and Learning Facilities of Science) on the dependent variable (Science Learning Outcomes) of Grade V students in Elementary Schools in Kabanjahe District. This analysis is assisted by the SPSS 22.0 for Windows data processing program.

Based on the calculation results obtained, the results of multiple regression equations are as follows:

TABLE 5. Regression Coefficients

\begin{tabular}{|cc|r|r|}
\hline \multirow{2}{*}{} & & \multicolumn{2}{|c|}{$\begin{array}{c}\text { Unstandardized } \\
\text { Coefficients }\end{array}$} \\
\cline { 3 - 4 } & \multicolumn{1}{|c|}{ Model } & \multicolumn{1}{c|}{$\begin{array}{c}\text { Std. } \\
\text { Error }\end{array}$} \\
\hline 1 & (Constant) & 2,044 &, 985 \\
& Learning Style &, 104 &, 018 \\
& Motivation &, 130 &, 034 \\
& Science learning & & \\
facilities &, 123 &, 034 \\
\hline
\end{tabular}

From the SPSS data above, it can be explained as follows:

$\mathrm{Y}=\mathbf{2 , 0 4 4}+\mathbf{0 , 1 0 4 X 1}+\mathbf{0 , 1 3 0 X 2}+\mathbf{0 , 1 2 3 X 3}+\mathrm{e}$

- A constant of 2.044 states that if the variable X (learning styles, motivation and learning facilities of science) does not change (constant) then the learning outcomes of science will remain at 2.044 .

- Regression coefficient $\mathrm{X}_{1}$ of 0.104 indicates that an increase in one unit of Learning Style will increase science learning outcomes.

- The $\mathrm{X}_{2}$ regression coefficient of 0.130 indicates that an increase in one motivation unit will increase the science learning outcomes.

- $\mathrm{X}_{3}$ regression coefficient of 0.123 indicates that an increase in one unit of science learning facilities will increase the learning outcomes of science.

From the description above, it can be concluded that the Learning Styles, Motivation and Learning Facilities for Science affects students' Science Learning Outcomes.

\section{CONCLUSION}

Learning styles, motivation, and science learning facilities has a positive and significant effect on science learning outcomes at fifth grade students in Kabanjahe District. The magnitude of the simultaneous effect is shown by the coefficient of determination of 0.746 , which means that the three independent variables namely learning styles, motivation, and science learning facilities explain the dependent variable namely students' science learning outcomes of 0.746 or $74.6 \%$, while the remaining $25.4 \%$ is influenced by the other variables of this research.

Learning styles have a positive and significant influence on the learning outcomes at 5 grade students in Kabanjahe District. The amount of partial influence is indicated by the regression coefficient of 0.104 and the three independent variables, the learning tsyles is the one that has the smallest regression coefficient.

Motivation has a positive and significant influence on science learning outcomes at fifth grade students in Kabanjahe District. The magnitude of the partial effect is indicated by the regression coefficient of 0.130 and from the three independent variables, the motivation variable is the one that has the largest regression coefficient.

Science learning facilities have a positive and significant influence on science learning outcomes at fifth grade students in Kabanjahe District. The amount of partial influence is indicated by the regression coefficient of 0.123 .

\section{REFERENCES}

[1] BSNP. 2011.Kurikulum Tingkat Satuan Pendidikan Sekolah Dasar dan Madrasah Ibtidaiyah. Jakarta: Depdiknas.

[2] Rifani. 2015. Peringatan Pendidikan Indoenesia di Dunia Tahun 2015 (http://penggarisku.blogspot.co.id), diakses 15 oktober 2017.

[3] Uswatun.H. 2016. Pengaruh Model Pembelajaran Dan Kemampuan Berfikir Kritis Terhadapa Hasil Belajar IPA Kelas V SD Di Kelurahan Menteng Jakarta Pusat.Pendidikan Dasar Universitas Negeri Jakarta Vol. 7 Edisi 2. Diakses pada tanggal 27 Desember 2017.

[4] Dimyati dan Mujiono. 2006. Belajar dan Pembelajaran. Jakarta:PT Rineka Cipta.

[5] Sudjana. 2009. Metoda Statistik. Bandung: Tarsito. 
[6] Dalyono, M. 2010. Psikologi Pendidikan. Jakarta: Rineka Cipta.

[7] Slameto. 2012. Belajar dan Faktor-Faktor yang Mempengaruhinya. Jakarta: Rineka Cipta.

[8] A, M. Sardiman (2012) Interaksi dan Motivasi Belajar Mengajar. Jarum: PT Raja Grafindo Persada.

[9] Pusat Bahasa Departemen Pendidikan Nasional. (2001). Kamus Besar Bahasa Indonesia. Jakarta: Balai Pustaka.

[10] Muhroji.(2004). Manajemen Pendidikan. Surakarta: UMS Press

[11] Hamalik, O. 2009. Proses Belajar Mengajar. Jakarta: PT. Bumi Aksara.

[12] The Liang Gie.2002. Cara Belajar Yang Efisien. Yogyakarta : Pusat Kemajuan Studi.

[13] Anjayani,Y. 2013. Pengaruh Fasilitas Belajar Terhadap Motivasi Belajar Siswa pada Mata Pelajaran Produktif Atministrasi Perkantoran SMK Negeri 3 Bandung. Jurnal.UPI: Bandung. Diakses pada tanggal 1 Maret 2018.

[14] Sunadi, Lukman. 2013. Pengaruh Motivasi Belajar dan Pemanfaatan Fasilitas Belajar Terhadap Prestasi Belajar Siswa Pada Mata Pelajaran Ekonomi Kelas XI IPS di SMA Muhamadiyah 2 Surabaya.Jurnal.UNESA: Surabaya. Diakses pada tanggal 1 Maret 2018.

[15] Umar. H. (2002). Metode Riset Bisnis. Jakarta. PT Gramedia

[16] Uline, C. Megan Tschannen-Moran. 2007. The Wall Speak: The Interplay of Quality Facilities, a School Climate and Student Achievement.Jurnal. San Diego State University. The College of William and Mary: USA Diakses pada tanggal 1 Maret 2018.

[17] Heafner, T. 2004. School Facility Conditions and Student Academic Achievement. Jurnal. University of North Carolina: Charlotte. Diakses pada tanggal 1 Maret 2018. 